\title{
FAKTOR RESIKO YANG BERHUBUNAGN DENGAN KEJADIAN ABORTUS DI RSUD UNGARAN JAWA TENGAH
}

\author{
Sri Wahyuni ${ }^{1)}$ Ngadiyono $^{2)}$ Sri Sumarni ${ }^{3)}$ \\ yuni250781@gmail.com,ngdiyono@gmail.com, marninugroho@yahoo.com
}

\begin{abstract}
The maternal mortality rate one of them caused by abortion is $15-50 \%$.. Abortion (miscarriage) is bleeding that can lead to termination of pregnancy. Factors which are suspected predisposing factors eg abortion of the fetus, maternal factors, environmental factors, age, parity, work and history of abortion. The results of a preliminary survey conducted in hospitals Ungaran researchers obtained data is abortion in 2015, there were 245 cases The aims of this study is to determine the risk factors that influence the incidence of abortion at Ungaran hospitals.

This study is a correlative study, with retrospective design. The population that was used in this research was all first trimester pregnant women who were treated at Ungaran hospitals. They experienced abortion during Januari to Desember 2015. The total number who recruited were 245 pregnant women as a total sample. The univariate analysis with frequency distribution and bivariate using Kruskal Walis Test were used

There is no relationship between maternal age with the incidence of abortion $(\mathrm{p}=0.349>0.05)$ No relationship between parity with the incidence of abortion $(\mathrm{p}=0.826>$ 0.05). There was no relationship between the working status with the incidence of abortion $(\mathrm{p}=0.114>0.05)$. There is a relationship between the history of the abortion with the incidence of abortion at Ungaran hospital $(\mathrm{p}=0.022<0.05)$, with a coefficient correlation value of 1.6. No relationship between maternal age, parity and working status with the incidence of abortion. However, history of abortion is a risk factor to be the incidence of abortion with a 1.6 times greater than those who don't have history of abortion.

Midwives are expected to anticipate the incidence of abortion by further improving supervision, especially to pregnant women with risk factors for abortion.
\end{abstract}

Keywords: Risk factors, abortion

${ }^{1)},{ }^{2},{ }^{3)}$ Dosen Poltekkes Semarang

Menurut Organisasi Kesehatan Dunia (WHO) 15-50\% kematian ibu disebabkan oleh abortus. Didunia angka kematian ibu dan bayi yang tertinggi adalah di Asia Tenggara, menurut data WHO persentase kemungkinan terjadinya abortus cukup tinggi. Sekitar 15$40 \%$ angka kejadian, diketahui pada ibu yang sudah dinyatakan positif hamil, dan 60-75\% angka abortus terjadi sebelum usia kehamilan mencapai 12 minggu ( Lestariningsih, 2008).

Di dunia terjadi 20 juta kasus abortus tiap tahun dan 70.000 wanita meninggal karena abortus tiap tahunnya. Angka kejadian abortus di Asia Tenggara adalah 4,2 juta pertahun termasuk Indonesia, sedangkan frekuensi abortus spontan di Indonesia adalah 10-15\% dari 6 juta kehamilan setiap tahunnya atau 600.000 - 900.000, 
sedangkan abortus buatan sekitar 0,75 - 1,5 juta setiap tahunnya, 2500 orang diantaranya berakhir dengan kematian (Anshor, 2006).

Berdasarkan SDKI 2012 Angka Kematian Ibu (AKI) ( yang berkaitan dengan kehamilan, persalinan dan nifas) sebesar 359 per 100.000 kelahiran hidup. AKI Indonesia yang mencapai 305 per 100.000 pada tahun 2015, Penyebab langsung kematian ibu tahun 2013 adalah pendarahan 30,3\%, hipertensi $27,1 \%$, infeksi $7,3 \%$, partus lama $0 \%$, abortus $0 \%$, lain-lain $40,8 \%$, (Kemenkes RI, 2015). AKI Jawa Tengah tahun 2014 sebesar 111,16 per100.000 kelahiran hidup dan AKB 10,08/1000 kelahiran hidup (Dinkes Prov Jateng, 2015). AKI Kabupaten Semarang tahun 2015 sebanyak 120,34 per $100.000 \mathrm{KH}$ dan AKB 11,18 per 1000 kelahiran hidup. Kematian ibu tertinggi adalah karena eklampsia $(48,48 \%)$, Penyebab lainnya adalah karena perdarahan $(24,24 \%)$, disebabkan karena penyakit sebesar $18,18 \%$, Infeksi sebesar 3,03\% dan lain-lain sebesar 6,06\%, dengan kondisi saat meninggal paling banyak pada masa nifas yaitu $54,55 \%$ diikuti waktu bersalin $(27,2 \%)$.

Abortus ( keguguran ) merupakan salah satu penyebab perdarahan yang terjadi pada kehamilan trimester pertama dan kedua. Perdarahan ini dapat menyebabkan berakhirnya kehamilan atau kehamilan terus berlanjut. Secara klinis, $10-15 \%$ kehamilan yang terdiagnosis berakhir dengan abortus (Wiknjosastro, 2010).

Abortus sangat berbahaya jika dilakukan oleh tenaga yang belum terlatih.Karena dapat mengakibatkan kematian akibat perdarahan yang terus menerus dan infeksi pada saat melakukan abortus. Di samping itu aborsi juga berdampak pada kondisi psikologis. Perasaan sedih karena kehilangan bayi, beban batin akibat timbulnya perasaan bersalah dan penyesalan yang dapat mengakibatkan depresi.

Beberapa faktor yang merupakan predisposisi terjadinya abortus missalnya faktor janin, faktor maternal, faktor lingkungan, umur, paritas, pekerjaan dan riwayat abortus. Resiko abortus semakin tinggi dengan bertambahnya paritas dan semakin bertambahnya usia ibu (Myles, 2009). Resiko abortus spontan meningkat seiring dengan paritas serta usia ibu dan ayah. Frekuensi abortus yang secara klinis terdeteksi meningkat $12 \%$ pada wanita berusia kurang dari 20 tahun menjadi $26 \%$ pada mereka yang usianya lebih dari 40 tahun (Obstetri Williams, Cunningham, 2010 ). Riwayat obstetrik sebelumnya merupakan prediktor terjadinya keguguran spontan. Multigravida secara signifikan beresiko lebih besar dibandingkan primigravida, dan keguguran yang terjadi pada kehamilan sebelumnya merupakan indikator risiko utama.

Riwayat abortus pada penderita abortus juga merupakan predisposisi terjadinya abortus berulang. Kejadiannya sekitar 3-5\%. Data dari beberapa studi menunjukkan bahwa setelah 1 kali abortus spontan, pasangan punya resiko $15 \%$ untuk mengalami keguguran lagi sedangkan bila pernah 2 kali, resikonya akan meningkat $25 \%$. Beberapa studi meramalkan bahwa resiko abortus setelah 3 kali abortus berurutan adalah 30-45\% (Prawirohardjo, 2009).

Kejadian abortus yang terjadi dapat menimbulkan komplikasi dan dapat menyebabkan kematian. Komplikasi abortus yang dapat menyebabkan kematian ibu antara lain karena perdarahan dan infeksi. Perdarahan yang terjadi selama abortus dapat mengaki- 
batkan pasien menderita anemia, sehingga dapat meningkatkan risiko kematian ibu. Salah satu jenis abortus spontan yang menyebabkan terjadi perdarahan yang banyak adalah abortus inkomplit. Hal ini terjadi karena sebagian hasil konsepsi masih tertinggal di plancental site. Sisa hasil konsepsi inilah yang harus ditangani agar perdarahan berhenti. Selain dari segi medis, abortus juga dapat menimbulkan dampak negatif pada aspek psikologi dan aspek sosioekonomi. Abortus seringkali terjadi pada wanita hamil dan membawa dampak psikologis yang mendalam seperti trauma, depresi hingga kecenderungan perilaku bunuh diri.

Kejadian abortus di Rumah Sakit lebih tinggi karena menerima rujukan. Bedasarkan data sekunder (Register pasien) penderita abortus di RSUD Ungaran pada Tahun 2010 sebanyak 211 kasus, tahun 2011 meningkat menjadi 294 kasus dan pada tahun 2012 meningkat menjadi 300 kasus. Dari 300 kasus tersebut terdapat $201 \quad(67 \%)$ kasus abortus iminens, 78 (26\%) kasus abortus inkompletus, 13 (4\%) kasus missed abortion $8(3 \%)$.

Dari penelitian yang dilakukan oleh Putri Novita Rochmawati ( 2012 ) mengenai Faktor - faktor yang mempengaruhi abortus di Rumah Sakit Umum Pusat dr Soeradji Tirtonegoro Klaten periode Januari - Desember 2012;, diperoleh hasil penelitian ibu hamil dengan usia $<20$ tahun atau $>35$ tahun yang mengalami abortus sebanyak 143 responden $(52,3 \%)$ dari 194 responden, usia 20-30 tahun sebanyak 51 responden $(13,7 \%)$; ibu dengan interval kehamilan $<2$ tahun mengalami abortus sebanyak 138 responden ( $37,2 \%$ ) sedangkan interval kehamilan $>2$ tahun 56 responden $(15,1 \%)$; ibu dengan paritas 1 atau > 3 terdapat 140 responden $(48,2 \%)$ sedangkan paritas 2-3 terdapat 54 responden $(14,6 \%)$.

Hasil survey pendahuluan yang dilakukan peniliti di RSUD Ungaran 2015 didapatkan data kejadian abortus tercatat sebanyak 245 kasus terdiri dari abortus iminen 155 kasus ( 63,3\%), abortus inkomplet 48 kasus $(19,6 \%)$, abortus insipien 6 kasus $(2,4 \%)$, blight ovum 24 kasus $(9,8 \%)$, missed abortion 12 kasus $(4,9)$.

Berdasarkan data di atas peniliti tertarik untuk melakukan penelitian khususnya tentang faktor resiko yang mempengaruhi kejadian abortus (usia, paritas, riwayat abortus, pekerjaan) dan macam-macam kejadian abortus di ruang bersalin RSUD Ungaran kab. Semarang.

\section{METODE}

Pendekatan yang digunakan adalah retrospektif yaitu penelitian yang berusaha melihat kebelakang (Backward Looking). Populasi yang akan digunakan dalam penelitian ini adalah semua ibu hamil Trimester I yang di rawat di RSUD Ungaran yang mengalami abortus selama periode Januari sampai Desember 2015 sebanyak 245 ibu hamil. Teknik sampling yang akan digunakan dalam penelitain ini adalah total sampling. Data yang digunakan dalam penelitian ini adalah data sekunder yaitu dengan cara mengobservasi dari data rekam medik klien ibu hamil Trimester I yang terdiagnosa abortus dalam kurun waktu sejak Januari sampai dengan Desember 2015 yang di rawat di RSUD Ungaran. Analisis univariat dalam penelitian ini dengan menggunakan distribusi frekuensi Anaisis bivariat menggunakan uji Chi Square 


\section{HASIL}

Analisis bivariat pada bagian ini digunakan untuk menyajikan hasil analisis faktor-faktor yang mempenga- ruhi kejadian abortus di RSUD Ungaran. Untuk menganalisis faktorfaktor tersebut digunakan uji KruskalWallis, yang mana hasilnya disajikan sebagai berikut:

Tabel 1.

Hubungan usia ibu hamil terhadap kejadian abortus di RSUD Ungaran

\begin{tabular}{|c|c|c|c|c|c|c|c|c|c|c|c|c|c|}
\hline \multirow{3}{*}{ Usia } & \multicolumn{10}{|c|}{ Abortus } & & & \multirow{3}{*}{$P$ value } \\
\hline & \multicolumn{2}{|c|}{$\begin{array}{c}\text { Abortus } \\
\text { Imminens }\end{array}$} & \multicolumn{2}{|c|}{$\begin{array}{c}\text { Abortus } \\
\text { Insipiens }\end{array}$} & \multicolumn{2}{|c|}{$\begin{array}{c}\text { Abortus } \\
\text { Incompletus }\end{array}$} & \multicolumn{2}{|c|}{$\begin{array}{l}\text { Missed } \\
\text { Abortus }\end{array}$} & \multicolumn{2}{|c|}{$\begin{array}{l}\text { Blight } \\
\text { Ovum }\end{array}$} & \multicolumn{2}{|c|}{ Total } & \\
\hline & $\mathrm{f}$ & $\%$ & $\mathrm{f}$ & $\%$ & f & $\%$ & $\mathrm{f}$ & $\%$ & $\mathrm{f}$ & $\%$ & $\mathrm{f}$ & $\%$ & \\
\hline $\begin{array}{l}<20 \\
\text { tahun } \\
\text { dan }> \\
35 \\
\text { tahun } \\
\end{array}$ & 35 & 57,4 & 4 & 6,6 & 12 & 19,7 & 2 & 3,3 & 8 & 13,1 & 61 & 100 & 0,349 \\
\hline $\begin{array}{l}20-35 \\
\text { tahun }\end{array}$ & 120 & 65,2 & 2 & 1,1 & 36 & 19,6 & 10 & 5,4 & 16 & 8,7 & 184 & 100 & \\
\hline Total & 155 & 63,3 & 6 & 2,4 & 48 & 19,6 & 12 & 4,9 & 24 & 9,8 & 245 & 100 & \\
\hline
\end{tabular}

Berdasarkan tabel 1 dapat diketahui bahwa mayoritas responden dengan umur $<20$ tahun dan $>35$ tahun mengalami abortus imminens yaitu 35 responden $(57,4 \%)$, hal tersebut juga terjadi pada responden yang berumur 20-35 tahun yang mayoritas juga mengalami abortus imminens yaitu 120 responden $(65,2 \%)$. Sedangkan hasil p-value analisis Kruskal-Wallis didapatkan $0,349>\alpha(0,05)$. Ini artinya tidak ada hubungan usia ibu hamil terhadap kejadian abortus di RSUD Ungaran.

Tabel 2

Hubungan paritas terhadap kejadian abortus di RSUD Ungaran

\begin{tabular}{|c|c|c|c|c|c|c|c|c|c|c|c|c|c|}
\hline \multirow{3}{*}{ Paritas } & \multicolumn{10}{|c|}{ Abortus } & & & \multirow{3}{*}{$\begin{array}{c}P \\
\text { value }\end{array}$} \\
\hline & \multicolumn{2}{|c|}{$\begin{array}{l}\text { Abortus } \\
\text { Imminens }\end{array}$} & \multicolumn{2}{|c|}{$\begin{array}{c}\text { Abortus } \\
\text { Insipiens }\end{array}$} & \multicolumn{2}{|c|}{$\begin{array}{c}\text { Abortus } \\
\text { Incomplet } \\
\text { us }\end{array}$} & \multicolumn{2}{|c|}{$\begin{array}{l}\text { Missed } \\
\text { Abortus }\end{array}$} & \multicolumn{2}{|c|}{$\begin{array}{l}\text { Blight } \\
\text { Ovum }\end{array}$} & \multicolumn{2}{|c|}{ Total } & \\
\hline & f & $\%$ & f & $\%$ & $\mathrm{f}$ & $\%$ & $\mathrm{f}$ & $\%$ & f & $\%$ & F & $\%$ & \\
\hline Primipara & 52 & 63,4 & 0 & 0 & 16 & 9,5 & 6 & 7,3 & 8 & 9,8 & 82 & 100 & \\
\hline Mutipara & 103 & 63,2 & 6 & 3,7 & 32 & 19,6 & 6 & 3,7 & 16 & 9,8 & 163 & 100 & 0,826 \\
\hline Total & 155 & 63,3 & 6 & 2,4 & 48 & 19,6 & 12 & 4,9 & 24 & 9,8 & 245 & 100 & \\
\hline
\end{tabular}

Hasil penelitian pada tabel 2 dapat diketahui bahwa mayoritas responden dengan paritas primipara mengalami abortus imminens yaitu 52 responden $(63,4 \%)$, hal tersebut juga terjadi pada responden dengan paritas multipara 
yang mayoritas juga mengalami abortus imminens yaitu 103 responden $(63,2 \%)$. Sedangkan hasil p-value analisis Kruskal Wallis didapatkan 0,826 > $\alpha(0,05)$. Ini artinya tidak ada hubungan Tabel 3

Hubungan riwayat abortus terhadap kejadian abortus di RSUD Ungaran

\begin{tabular}{|c|c|c|c|c|c|c|c|c|c|c|c|c|c|}
\hline \multirow{3}{*}{$\begin{array}{c}\text { Riwayat } \\
\text { abortus }\end{array}$} & \multicolumn{10}{|c|}{ Abortus } & & & \multirow{3}{*}{$P$ value } \\
\hline & \multicolumn{2}{|c|}{$\begin{array}{l}\text { Abortus } \\
\text { Imminens }\end{array}$} & \multicolumn{2}{|c|}{$\begin{array}{l}\text { Abortus } \\
\text { Insipiens }\end{array}$} & \multicolumn{2}{|c|}{$\begin{array}{c}\text { Abortus } \\
\text { Incompletus }\end{array}$} & \multicolumn{2}{|c|}{$\begin{array}{l}\text { Missed } \\
\text { Abortus }\end{array}$} & \multicolumn{2}{|c|}{$\begin{array}{l}\text { Blight } \\
\text { Ovum }\end{array}$} & \multicolumn{2}{|c|}{ Total } & \\
\hline & $\mathrm{f}$ & $\%$ & $\mathrm{f}$ & $\%$ & $\mathrm{f}$ & $\%$ & $\mathrm{f}$ & $\%$ & $\mathrm{f}$ & $\%$ & F & $\%$ & \\
\hline Tidak & 103 & 58,9 & 4 & 2,3 & 39 & 22,3 & 9 & 5,1 & 20 & 11,4 & 175 & 100 & \\
\hline Ya & 52 & 74,3 & 2 & 2,9 & 9 & 12,9 & 3 & 4,3 & 4 & 5,7 & 70 & 100 & $0,0<2$ \\
\hline Total & 155 & 63,3 & 6 & 2,4 & 48 & 19,6 & 12 & 4,9 & 24 & 9,8 & 245 & 100 & \\
\hline
\end{tabular}

Hasil penelitian pada tabel 3 dapat diketahui bahwa mayoritas responden yang tidak memiliki riwayat abortus mengalami abortus imminens yaitu 103 responden $(58,9 \%)$, hal tersebut juga terjadi pada responden dengan riwayat abortus yang mayoritas juga menga- paritas terhadap kejadian abortus di RSUD Ungaran.

Tabel 4

Hubungan pekerjaan terhadap kejadian abortus di RSUD Ungaran

\begin{tabular}{|c|c|c|c|c|c|c|c|c|c|c|c|c|c|}
\hline \multirow{3}{*}{ Pekerjaan } & \multicolumn{10}{|c|}{ Abortus } & & & \multirow{3}{*}{$P$ value } \\
\hline & \multicolumn{2}{|c|}{$\begin{array}{c}\text { Abortus } \\
\text { Imminens }\end{array}$} & \multicolumn{2}{|c|}{$\begin{array}{c}\text { Abortus } \\
\text { Insipiens }\end{array}$} & \multicolumn{2}{|c|}{$\begin{array}{c}\text { Abortus } \\
\text { Incompletus }\end{array}$} & \multicolumn{2}{|c|}{$\begin{array}{l}\text { Missed } \\
\text { Abortus }\end{array}$} & \multicolumn{2}{|c|}{$\begin{array}{l}\text { Blight } \\
\text { Ovum } \\
\end{array}$} & \multicolumn{2}{|c|}{ Total } & \\
\hline & f & $\%$ & f & $\%$ & f & $\%$ & f & $\%$ & $\mathrm{f}$ & $\%$ & $\mathrm{f}$ & $\%$ & \\
\hline $\begin{array}{l}\text { Tidak } \\
\text { bekerja }\end{array}$ & 122 & 66,7 & 5 & 2,7 & 30 & 16,4 & 5 & 2,7 & 21 & 11,5 & 183 & 100 & \\
\hline Bekerja & 33 & 53,2 & 1 & 1,6 & 18 & 29,0 & 7 & 11,3 & 3 & 4,8 & 62 & 100 & 0,114 \\
\hline Total & 155 & 63,3 & 6 & 2,4 & 48 & 19,6 & 12 & 4,9 & 24 & 9,8 & 245 & 100 & \\
\hline
\end{tabular}

Hasil penelitian pada tabel 4 dapat diketahui bahwa mayoritas responden yang tidak bekerja mengalami abortus imminens yaitu 122 responden $(66,7 \%)$, hal tersebut juga terjadi pada responden yang bekerja mayoritas juga mengalami abortus imminens yaitu 33 responden $(53,2 \%)$. Sedangkan hasil pvalue analisis Kruskal-Wallis didapatkan $0,114>\alpha(0,05)$. Ini artinya tidak ada lami abortus imminens yaitu 52 responden $(74,3 \%)$. Sedangkan hasil p-value analisis Kruskal Wallis didapatkan 0,022 $<\alpha(0,05)$. Ini artinya ada hubungan riwayat abortus terhadap kejadian abortus di RSUD Ungaran. hubungan pekerjaan ibu terhadap kejadian abortus di RSUD Ungaran.

Analisis multivariat pada bagian ini digunakan untuk menyajikan hasil analisis faktor yang paling berhubungan dengan kejadian abortus di RSUD Ungaran. Untuk menganalisis faktorfaktor tersebut digunakan uji regresi logistik, pada analisis bivariat hanya 
variabel rivayat abortus yang berhubungan sehingga analisis ini digunakan untuk mengetahui seberapa persen riwayat abortus berpengaruh dengan kejadian abortus.

Tabel 5.

Hasil koefisien korelesai variabel riwayat abortus dengan kejadian abortus.

\begin{tabular}{lcc}
\hline Variabel & $\begin{array}{c}\text { Koefisien } \\
\text { korelasi }\end{array}$ & P value \\
\hline $\begin{array}{l}\text { Riwayat } \\
\text { abortus }\end{array}$ & 1,6 & 0,025 \\
\hline
\end{tabular}

Hasil penelitian pada tabel 5 dapat diketahui bahwa hasil p-value analisis regresi linier didapatkan $0,025<\alpha$ $(0,05)$. Ini artinya ada pengaruh riwayat abortus terhadap kejadian abortus di RSUD Ungaran, nilai koefesien kolerasi 1,6 yang berarti ibu yang memiliki riwayat abortus 1,6 kali lebih besar mengalami resiko abortus dibanding ibu yang tidak memiliki riwayat abortus.

\section{PEMBAHASAN}

Hasil penelitian diketahui bahwa mayoritas responden dengan umur $<20$ tahun dan > 35 tahun mengalami abortus imminens yaitu 35 responden $(57,4 \%)$, hal tersebut juga terjadi pada responden yang berumur 20-35 tahun yang mayoritas juga mengalami abortus imminens yaitu 120 responden $(65,2 \%)$. Sedangkan hasil p-value analisis Kruskal-Wallis didapatkan $0,349>\alpha(0,05)$. Ini artinya tidak ada hubungan usia ibu hamil terhadap kejadian abortus di RSUD Ungaran. Hal ini menunjukkan bahwa umur ibu bukan merupakan faktor yang resiko terjadinya abortus masih terdapat faktor lain yang lebih beresiko mengalami abortus.

Hasil penelitian ini sesuai dengan penelitian sebelumnya yang dilakukan oeh Fajria (2013) yang didapatkan hasil bahwa faktor umur, faktor paritas, faktor riwayat penyakit dan faktor jarak kehamilan dengan yang sebelumnya tidak menunjukkan hasil yang signifikan terhadap resiko kejadian abortus. Hal ini dapat terjadi karena adanya faktor lain yang lebih dominan dari berbagai faktor tersebut. Hasil penelitian ini didukung oleh penelitian Rahmani (2013) dimana diperoleh hasil ibu yang berusia $20-35$ tahun ada $84,4 \%$ yang mengalami abortus.

Tidak menutup kemungkinan bagi ibu umur 20-35 tahun (reproduksi sehat) untuk megalami komplikasi dalam kehamilan. Sehingga semua ibu memerlukan pemantauan selama hamil (Saifuddin, 2010). Sastrawinata (2005) menyatakan bahwa penyebab abortus yang paling utama adalah faktor janin yang meliputi kelainan telur, kerusakan embrio, kelainan kromosom dan abnormalitas pembentukan plasenta. Faktor maternal yang meliputi infeksi maternal, penyakit, kelainan uterus, faktor imunologi dan trauma.

Hasil penelitian diketahui bahwa mayoritas responden dengan paritas primipara mengalami abortus imminens yaitu 52 responden $(63,4 \%)$, hal tersebut juga terjadi pada responden dengan paritas multipara yang mayoritas juga mengalami abortus imminens yaitu 103 responden $(63,2 \%)$. Sedangkan hasil p-value analisis Krus-kalWallis didapatkan $0,826>\alpha(0,05)$. Ini artinya tidak ada hubungan paritas terhadap kejadian abortus di RSUD Ungaran

Paritas merupakan faktor penting yang dapat mempengaruhi kehamilan maupun persalinan, karena kemungkinan terjadinya kesakitan dan kematian maternal. Paritas lebih dari 5 dan ibu primipara memiliki resiko lebih tinggi dalam proses kehamilan dan persalin- 
an. Ibu dengan paritas rendah atau cenderung mengalami komplikasi yaitu bayi yang dilahirkannya tidak matur atau ada komplikasi karena merupakan pengalaman pertama terhadap kemampuan alat reproduksi ibu. Hal ini akan berdampak negatif pada janin yaitu bertumbuhan yang tidak maksimal dan meningkatkan resiko terjadi abortus dan BBLR (Mochtar, 2005)

Hasil penelitian menunjukkan bahwa sesuai dengan teori, tidak ada hubungan paritas terhadap kejadian abortus, hal ini dapat dikarenakan tidak hanya paritas ibu yang mempengaruhi abortus terdapat faktor lain seperti faktor janin seperti gangguan pertumbuhan zigot, embrio, janin, dan plasenta. Infeksi pada ibu, trauma dan faktor ingkungan (Sastrawinata, 2005)

Hasil penelitian ini sesuai dengan penelitian Dede Mahdiyah tahun 2013 yang mengungkapkan bahwa tidak ada hubungan yang bermakna antara paritas dengan kejadian abortus di ruang bersalin RSUD Dr. H Moch Ansari Saleh Banjarmasin pada tahun 2012.

Hasil penelitian dapat diketahui bahwa mayoritas responden yang tidak memiliki riwayat abortus mengalami abortus imminens yaitu 103 responden $(58,9 \%)$, hal tersebut juga terjadi pada responden dengan riwayat abortus yang mayoritas juga mengalami abortus imminens yaitu 52 responden $(74,3 \%)$. Sedangkan hasil p-value analisis Kruskal-Wallis didapatkan $0,022<\alpha$ $(0,05)$. Ini artinya ada hubungan riwayat abortus terhadap kejadian abortus di RSUD Ungaran.

Hal ini sesuai dengan teori bahwa diperkirakan bahwa kurang dari $4 \%$ keguguran berkaitan dengan aborsi yang pernah dilakukan sebelumnya. Bila sebelumnya pernah mengalami keguguran, memang sedikit meningkat- kan terulangnya keguguran, tetapi statistic menunjukkan bahwa kesempatan untuk berhasil adalah $70 \%$ setelah dua kali keguguran dan $68 \%$ setelah tiga kali keguguran atau lebih (Murphy, 2005). Riwayat abortus menunjukkan bahwa kondisi rahim yang kurang baik atau adanya kelainan pada kehamilan sebelumnya, hal ini akan beresiko mengalami abortus pada kehamilan berikutnya bila tidak tertangani dengan baik. Riwayat abortus menjadi faktor yang paling berhubungan dengan abortus imminens dikarena ibu yang telah memiliki pengalaman mengalami kejadian abortus sebelumnya sehingga mengetahui tanda dan gejala abortus dan lebih berhati-hati, saat ibu mengalami tanda abortus tersebut ibu akan bergegas datang ke tenaga kesehatan untuk memeriksakan kehamilan, sehingga sampai di fasilitas kesehatan diagnosa ibu adalah abortus imminens atau mengancam

Hal ini sesuai dengan penelitian sebelumnya oleh Masitoh (2013) dimana didapatkan hasil ibu dengan riwayat abortus memiliki proporsi sebanyak $55,6 \%$ untuk mengalami abortus imminens. Setelah diuji dengan statistic chi square ternyata didapatkan nilai $\mathrm{p}=$ 0,004 (nilai $\mathrm{p}<0,005$ ) sehingga dapat disimpulkan bahwa terdapat hubungan bermakna antara riwayat abortus dengan kejadian abortus imminens, riwayat abortus berisiko 4,2 kali > besar dari ibu yang tidak memiliki riwayat abortus.

Hasil penelitian dapat diketahui bahwa mayoritas responden yang tidak bekerja mengalami abortus imminens yaitu 122 responden $(66,7 \%)$, hal tersebut juga terjadi pada responden yang bekerja mayoritas juga mengalami abortus imminens yaitu 33 responden $(53,2 \%)$. Sedangkan hasil 
p-value analisis Kruskal-Wallis didapatkan $0,114>\alpha(0,05)$. Ini artinya tidak ada hubungan pekerjaan ibu terhadap kejadian abortus di RSUD Ungaran. Hal ini tidak sesuai dengan teori bahwa angka abortus ditemukan bertambah pada wanita yang bekerja mengangkat barang berat dan berdiri berjam-jam, atau pajanan terhadap kebisingan yang berlebih, getaran atau udara dingin. Perawat rumah sakit serta wanita di industri plastik dan pertanian mempunyai resiko yang lebih tinggi ( Jeyaratnam \& Koh, 2012). Klein dan Thomson (2008) mengungkapkan bahwa abortus sangat dipengaruhi oleh kondisi ibu. Apabila ibu terlalu banyak bekerja atau beraktivitas akan memicu terjadinya abortus. Beban kerja yang terlalu berat membuat ibu capek baik secara fisik atau mental, hingga mengakibatkan beberapa gangguan kesehatan.

Hasil penelitian ini tidak sesuai dengan teori diatas dapat dikarenakan terdapat faktor lain yang mempengaruhi abortus terdapat faktor lain seperti faktor janin seperti gangguan pertumbuhan zigot, embrio, janin, dan plasenta. Infeksi pada ibu, trauma dan faktor ingkungan (Sastrawinata, 2005). Hal diatas sesuai dengan penelitian sebelumnya oleh Kurniasih (2013) di Di Pt X Kabupaten Sumedang Provinsi Jawa Barat dimana didapatkan hasil bahwa umur, paritas, jenis pekerjaan dan aktifitas kerja tidak berhubungan dengan kejadian abortus

Hasil penelitian dapat diketahui bahwa pada analisis bivariat hanya variabel riwayat abortus yang berhubungan, sehingga dilakukan regresi pada variabel tersebut hasil p-value analisis regresi linier didapatkan $0,025<$ $\alpha(0,05)$. Ini artinya ada pengaruh riwayat abortus terhadap kejadian abortus di RSUD Ungaran, nilai koofesien kolerasi 1,6 yang berarti ibu yang memiliki riwayat abortus 1,6 kali lebih besar mengalami resiko abortus dibanding ini yang tidak memiliki riwayat abortus. Hal ini menunjukkan bahwa kemungkinan besar terjadi abortus secara berulang adalah 1,6 kali sehingga setiap ibu dengan riwayat abortus membutuhkan perhatian lebih agar tidak kembali mengalami abortus pada kehamilan berikutnya.

Hal ini sesuai dengan teori yang dinyatakan oleh Prawirohardjo (2008) bahwa kejadian abortus meningkat pada wanita yang memiliki riwayat abortus sebelumnya. Setelah satu kali mengalami abortus spontan, memiliki risiko $15 \%$ untuk mengalami keguguran lagi, sedangkan bila pernah dua kali, risikonya meningkat sebesar $25 \%$. Beberapa studi meramalkan bahwa risiko abortus setelah tiga kali abortus berurutan adalah $30-45 \%$

Penelitian yang dilakukan Lukitasari (2010) di RS H.M Ryacudu Kotabumi Lampung Utara yang mendapatkan bahwa terdapat hubungan yang signifikan (nilai $\mathrm{p}=0,0001$ ) antara riwayat abortus yang dimiliki ibu dengan kejadian abortus. Penelitian lain menurut Wahyuni (2012) di wilayah puskesmas Sungai Kakap Kabupaten Kubu Raya Kalimantan Barat bahwa ada hubungan (nilai $\mathrm{p}=0,04$ ) antara riwayat abortus dengan kejadian abortus. Selain itu pasien yang pernah mengalami abortus akan cencerung mengalami abortus sebesar 2,8 kali dibandingkan pasien yang tidak pernah mengalami abortus

\section{PENUTUP}

Ibu hamil trimester I yang mengalami abortus di RSUD Ungaran, sebagian besar berumur 20-35 tahun 
yaitu 75,1\%. Paritas ibu sebagian besar merupakan ibu multipara yaitu $66,5 \%$. Sebagian besar ibu tidak memiliki riwayat abortus yaitu $71,4 \%$. Pekerjaan ibu sebagian besar tidak bekerja yaitu $74,7 \%$. Jenis abortus yang dialami oleh ibu hamil sebagian besar abortus imminens yaitu $63,3 \%$. Tidak ada hubungan usia ibu hamil terhadap kejadian abortus di RSUD Ungaran dengan nilai $p$ value $0,349>0,05$. Tidak ada hubungan paritas terhadap kejadian abortus di RSUD Ungaran dengan nilai $p$ value $0,826>0,05$. Ada hubungan riwayat abortus terhadap kejadian abortus di RSUD Ungaran dengan nilai $p$ value $0,022<0,05$. Tidak ada hubungan pekerja terhadap kejadian abortus di RSUD Ungaran dengan nilai $p$ value $0,114>0,05$. Ibu yang memiliki riwayat abortus 1,6 kali lebih besar mengalami resiko abortus dibanding ini yang tidak memiliki riwayat abortus. Hasil penelitian ini diharapkan keluarga dan ibu hamil menjaga kandungannya terutama pada kehamilan trimester I dimana masih merupakan usia yang rawan untuk terjadinya abortus dan melakukan antenatal care secara rutin untuk mengetahui kesehatan ibu dan janin.

Tenaga kesehatan khususnya bidan agar melakukan antisipasi terhadap kejadian abortus dengan lebih meningkatkan asuhan kebidanan yang harus diberikan terutama kepada ibu hamil dengan faktor resiko

\section{Acknowledgement}

Penelitian ini mendapatkan surat persetujuan atau ethical Clearance dari Komite Etik Penelitian Kesehatan Poltekkes Kemenkes Semarang dengan nomor 190/ KEPK/ Poltekkes-Smg/ EC /2017 pada tanggal 20 Maret 2017.

Ucapan terimakasih disampaikan kepada Direktur RSUD Ungaran, kepa- la Dinas Kesehatan Kabupaten Semarang, mitra sejawat bidan, responden, dan semua pihak yang terlibat dalam penelitian ini.

\section{DAFTAR PUSTAKA}

Anshor. 2006. Jurnal Dinamika Kesehatan, Vol. 12. No. 12. 17 Desember 2013

Arisman. 2010. Gizi Dalam Daur Kehidupan. Jakarta:Penerbit Buku Kedokteran. EGC.

Azizah. 2014. Hubungan Pekerjaan dan Status Gizi Ibu Hamil Dengan Kejadian Abortus Spontan Di RST Dr Asmir Salatiga. Program Studi DIV Kebidanan Stikes Ngudi Waluyo

Buku Register Ruang Bersalin. 2015. Regiter Pasien Masuk Rawat Inap Ruang Bersalin

Cunningham. 2010. Obstetri Williams. Jakarta: EGC.

Dede Mahdiyah. 2013. Hubungan Paritas dengan Kejadian Abortus di Ruang Bersalin RSUD Dr. H. Moch. Ansari Saleh Banjarmasin. Dinamika Kesehatan, vol 12.No 12. 17 Desember 2013.

Dinkes Provinsi Jawa Tengah. 2015. Profil Kesehatan Provinsi Jawa Tengah.

Dorland 2010. Kamus Kedokteran Dorland edisi 31. Jakarta: Penerbit Buku Kedokteran. EGC.

Elvira Junita. 2013. Hubungan Umur Ibu Hamil dengan Kejadian Abortus di RSUD Rokan Hulu. Jurnal Maternity and Neonatal vol 1 No 22013. 
Fajria. 2013. Analisis Faktor Resiko Kejadian Abortus di RSUP Dr. M.Djamil Padang. NERS JURNAL KEPERAWATAN VOLU ME 9, No 2, Oktober 2013 : 140-153

Hamidah, Siti Masitoh. 2013. Faktor Dominan Yang Berhubungan Dengan Kejadian Abortus Imminens. Jurnal Ilmu \& Teknologi Ilmu Kesehatan, Jilid 1, Nomor 1, September 2013, hlm : 29-33

Handayani. 2014. Gambaran Karakteristik Ibu Hamil Dengan Abortus Inkomplit Di RSU Kota Tangerang Selatan Periode 12 September 2013 - 12 Maret 2014

Hastono. 2007. Analisa Data Kesehatan. Jakarta: Universitas Indonesia

Hidayat. 2011. Metode Penelitian Kebidanan dan Tehnik Analisis Data. Jakarta : Salemba Medika.

Jelita . 2015. Gambaran Pekerjaan Ibu Hamil Trimester I Dengan Kejadian Abortus Di Rsia Kirana Sidoarjo. Midwiferia / Vol. 1 ; No. 2 / Oktober 2015

Jeyaratnam J. 2012. Buku Ajar Praktik Kedokteran Kerja. Jakarta: EGC.

Kementrian Kesehatan RI.2015. Profil Kesehatan Indonesia tahun 2015. Jakarta

Lestariningsih. 2008. Jurnal Maternity and Neonatal. Vol 1 No. 2. 2013

Lewellyn. 2005. Setiap Wanita. Jakarta. Dela Pratasa
Lieskusumastuti . 2016. Faktor Risiko Yang Berhubungan Dengan Kejadian Abortus Spontan Di Rsu Pku Muhammadiyah Delanggu Tahun 2016

Murphy,S. 2002. Keguguran: Apa yang Perlu Diketahui. Jakarta : Ardan

Mutmainnah. 2016. Faktor-Faktor Risiko Kejadian Abortus Di Rs Smc Samarinda. Jurnal Kebidanan Mutiara Mahakam Volume IV, Nomor 2, September 2016

Mochtar. 2005. Sinopsis Obstetri Jilid 1. Jakarta : EGC

Myles. 2009. Buku Ajar Bidan. Jakarta : EGC, 2009

Ni Ketut Kasmini. 2010. Studi Deskriptif Faktor-Faktor Penyebab Abortus Inkompletus pada Ibu Hamil di RS. Mardi Rahayu Kudus. Jurnal abortus 2010.

Notoatmodjo. 2010. Metodologi Penelitian Kesehatan. Jakarta: PT. Rineka Cipta.

Nurjaya, Muliati \& Umar, S. 2005. Faktor-Faktor Yang Berhubungan Dengan Kejadian Abortus Di RSIA Siti Fatimah Makassar Periode Juli-Desember 2005. Skripsi Tidak diterbitkan

Poerwadarminta, W.J.S. 2005. Kamus Umum Bahasa Indonesia. Edisi Ketiga. Jakarta: Balai Pustaka.

Pranata.2012. Kejadian Keguguran, Kehamilan Tidak Direncanakan Dan Pengguguran Di Indonesia. Buletin Penelitian Sistem Kesehatan - Vol. 15 No. 2 April 2012: 180-192 
Prawirohardjo, Sarwono. 2011. Ilmi Kebidanan edisi ke 2. Jakarta : Yayasan Bina Pustaka.

Pusdiknakes, 2003, Sistem Kesehatan Nasional. Jakarta : Depkes

Putri Nurvita Rochmawati. 2010. Faktor-Faktor yang Mempengaruhi Abortus di RSUP Dr. Soeradji Tirtonegoro Klaten. Jurnal Abortus 2010.

Rahmani. 2013. Gambaran Karakteristik Ibu Hamil Dengan Abortus Inkomplit Di RSU Kota Tangerang Selatan Periode 12 September 2013 - 12 Maret 2014.
Saifuddin. 2014. Buku Panduan Praktis Pelayanan Kontrasepsi. Jakarta : Yayasan Bina Pustaka Sarwono Prawirohardjo.

Sastrawinata, $d k k$. 2005. Ilmu Kesehatan Reproduksi : Obstetri Patologi.

Varney. 2006. Verney. 2006. Buku Ajar Asuhan Kebidanan. Jakarta. EGC

Wiknjosastro. 2010. Ilmu kebidanan. Jakarta : Yayasan Bina Pustaka Sarwono Prawirohardjo.. 